\title{
The Impact of Disclosure Sentiment on the Share Prices of Russian Companies
}

\author{
Maksim Kopyrin \\ Intern at International Laboratory of Intangible-Driven Economy \\ ORCID \\ E-mail: kopyrin.mak@yandex.ru \\ National Research University Higher School of Economics, Perm, Russia \\ Iuliia Naidenova $₫$ \\ Cand. Sci. (Econ.) \\ Junior researcher at International Laboratory of Intangible-Driven Economy \\ ORCID \\ E-mail: yunaydenova@hse.ru \\ National Research University Higher School of Economics, Perm, Russia
}

Journal of Corporate Finance Research, Vol. 15, No. 2, pp. 5-15 (2021)

For citation: Kopyrin, M. and Naidenova, I. (2021) “The Impact of Disclosure Sentiment on the Share Prices of Russian Companies”, Journal of Corporate Finance Research | ISSN: 2073-0438, 15(2), pp. 5-15. doi: 10.17323/j.jcfr.2073-0438.15.2.2021.5-15.

Received 15 April 2021 | Peer-reviewed 23 June 2021 | Accepted 24 July 2021 


\section{Abstract}

Information about companies published in a news feed is invariably tinted by emotional tonality. As such, resulting perceptions may influence the opinion of market players, and consequently affect the dynamics of a company's share price. This study aims to evaluate various hypotheses about the impact of the tone of news items regarding dividends, capital expenditures, and development on the stock prices of Russian companies. Information disclosure is extensively studied, and there have been limited studies on the effect of disclosures on Russian companies. However, until now, there have been no research studies which verify hypotheses on the influence of news sentiment on corporate share prices in the Russian market.

This analysis was conducted using data from 49 Russian public companies included in the Moscow exchange index over the period from the end of 2017 to the beginning of 2019. To account for the proximate impact of news items on consequential market phenomena, an event study methodology was applied in order to estimate and construct the models of dependency of cumulative abnormal return (CAR) on news tone level, and control for financial and non-financial factors.

Our results provide evidence for the positive impact of the tone of news texts on the share prices of Russian companies. The increase in news tone by one standard deviation leads to a cumulative abnormal stock return increase of 0.26 percentage points. This result is consistent with previous research conducted on data from developed stock markets. Moreover, the relationship between the tone or sentiment level of a news item and the stock price reaction is linear, without the diminishing marginal effect.

Our conclusions should prompt companies to invest effort in delivering information in a tonally positive way, highlighting the most positive news. Investors, in turn, should rationally approach the interpretation of published information.

Key words: corporate finance, sentiment analysis, event study, corporate disclosure, stock markets, financial report, news analysis. 


\section{Introduction}

Recent years have seen a growth in the amount of news about companies in the financial world. Such information, which traders get from various sources, assists them in constructing their trade strategies. The information providers are often companies involved in the industry themselves, including independent analysts, investment bank analysts, etc. However, the investors' expedience, especially when parsing such a vast amount of published information, remains disputable. In order to make a greater impact on market players, such news is often bestowed with a certain tone which may influence opinion about the news, and consequently the investors' response to new information.

The Russian stock market differs significantly from the more often analysed markets of the USA and Great Britain, having a significantly smaller number of companies, smaller amount of capital, and smaller trade volume. According to the World Bank, as at the end of 2018, the market capitalisation of companies in Russia equaled 576 billion US dollars, which accounts for just under 35\% of GDP. By way of comparison, similar indicators in the USA amounted to 30 trillion US dollars and $148 \%$ of GDP [1]. Apart from that, within the period under observation, many large Russian companies had a need for outside financing due to economic sanctions employed against Russia and certain organisations since 2014. Also, while distinctive features of the Russian stock market include a large number of public companies with public capital and an extremely low involvement of population in financial markets, the degree of population involvement grows every year. Thus, in 2018 the number of proactive individual investors increased from 94 thousand to 133 thousand persons, and the amount of assets doubled and attained 2 trillion roubles [2]. So, in spite of the great inclination of Russian economics towards bank financing, the stock market may potentially be a significant fund raising source for Russian companies. As long as shares are a risky investment tool, the response of the growing part of investors to the sentiment of events, and as a consequence, share prices of companies, are of special interest for research. Therefore analysis of investor behaviour as regards information disclosure, and in particular regarding the sentiment of conveyed text, is of relevance in the Russian stock market, and the results may differ from the conclusions of previous research [3-5].

In this research we consider the degree of influence of news sentiment on the share price of a company within the period from the fourth quarter of 2017 to January 2019 using the selection of companies from the Moscow exchange index.

The structure of this paper is as follows. First, we consider the results of theoretical and empirical research dedicated to the influence of information disclosure on share prices of companies. Then we analyse empirical research studies which show the influence of the news text sentiment on share prices. Further, we consider the ways of measuring the sentiment of information disclosure. Afterwards we present the selection of the research, and describe data and methodology stages. Finally, we define the results of empirical analysis and make conclusions.

\section{Influence of Information Disclosure on Corporate Share Prices}

Information disclosure is an extensively studied sphere. As a company activity it facilitates the reduction of information asymmetry between the management and investors [6], and helps investors to place capital in accordance with their preferences.

Companies may be interested in information manipulation in order to control share price dynamics. We identify such opportunities of control using disclosure as choice of the publication time, distortion, biased nature and concealment of information [7;8]. The emotional 'colouring' of news may also be a part of the strategy of information disclosure of a company, or an intended act of analysts intended to manipulate the prices of corporate securities.

In empirical studies, information disclosure is often considered as a separate information signal to which investors respond. Therein, fewer than all information signals cause response of the market.

Considering the influence of information disclosure on the stock markets of developed countries, T.D. Berry and K.M. Howe [9] assume that all information events in the aggregate may influence the share prices of companies. However, their hypothesis was not confirmed. Partly, they were forced to such a conclusion because they analysed all news for all time. Nevertheless, they found a positive influence of information disclosure on share prices in certain categories. H. Lee, E. Kweon, M. Kim and S. Chai [10] considered specific news events, divided them into categories, and evaluated the influence of disclosure of information on the use of big data analysis in a company on the share prices of such a company. As a result, they found a positive response of the stock market on news about the application of big data analysis by a company. Against this background, it may be noted that in the stock markets of Western countries the influence of information disclosure by categories was confirmed.

We also conducted research into the Russian stock market, dedicated to analysis of the influence of information disclosure on share prices. However, these results are controversial [11]. For example, I. Naidenova [12] proposed that players of the Russian stock market on average do not respond to R\&D news. She used as an example voluntary information disclosure on $R \& D$ by pharmaceutical companies. The research by A.V. Yavorskaya [13] showed a serious positive response to cross-listing news. The results of further study by A.V. Yavorskaya and V.M. Yavorskii [11] also showed a statistically significant response to the news only on the ninth day after publication, on the issue of depositary receipts. However, there are no research studies which verify hy- 
potheses on the influence of news sentiment on corporate share prices in the Russian market. Probably, it is due to the fact that it is difficult to assess the news about companies because the majority of news is published in Russian. Absence of such research may also be related to a low interest of the market players in using such technology in the Russian stock market. However, there exist companies which exhibit the proper indicator of the average daily trade volume for such research.

\section{The Text Sentiment and its Influence on Share Prices}

'Text sentiment analysis' has come into use relatively recently. One of the first papers in this regard is the research by W. Antweiler and M.Z. Frank [14]. Using the text mining approach, which divides news into 'bad' and 'good' categories, they found a positive dependence between the sentiment of financial news at Yahoo Finance and trading volatility.

As part of an assessment of the influence of news on the stock market, Y.C. Soon [3] applied the 'emotions analysis' method. As a result, the research confirmed the existence of a significant interrelation between the negatively-assessed news and the share price of the S\&P index companies. Thus, it may be noted that players in Western stock markets respond to the emotional colouring of events.

G. Ranco et al. [4] studied news from the Twitter social network from the point of view of emotional colouring. They found out a significant interrelation between the emotional colouring of news published in Twitter and the abnormal return of a security. Their results turned out to be relevant not just for expected peak amounts of publications in Twitter (for example, quarterly reports), but also for peaks which correspond to events less significant for the market. Consequently, we can draw the conclusion that information disclosure in social networks and its emotional colouring may influence corporate share prices even when it comes to a voluntary information disclosure.

As far as Russian research is concerned, the sentiment of information disclosure has a relatively minor effect on share prices. Nevertheless the results of the research by E.A. Fedorova et al. [15] confirmed a significant influence of the sentiment of the company's general directors' speeches addressed to shareholders on corporate share prices. Another research study by E.A. Fedorova et al. [16] showed a positive interrelation between the level of optimism in a CEO's speeches in annual corporate reports and the share prices of such companies. Consequently, we can make an hypothesis / suppose that Russian market players also tend to respond to information sentiment.

\section{Measuring of the Information Disclosure Sentiment}

An important part of this research is the choice of the methodology for defining the 'emotional load' of the news.
There are several ways of assessing the emotional colouring of a text. In earlier papers, the text sentiment was defined by three categories: positive, negative and neutral, and most often it was defined by experts [17; 18]. Alternatively, a more detailed classification may be applied. For example, N. Tabari, P. Biswas, B. Praneeth et al. [5], in a research study aimed at analysis of influence of news sentiment on Twitter, ask four experts to define the emotional colouring of events from -2 to 2 , where -2 is an extremely negative colouring, and 2 is an extremely positive one. On average the experts agree with each other in $82.8 \%$ of cases [5]. This shows the necessity to engage a range of experts in order to obtain a more objective estimation.

In further papers, analysis is focused on classification of emotions at the level of news articles using predetermined lexicons of emotional load. For the first time, the method was applied in the financial sphere by W. Antweiler and M.Z. Frank [14], who used language algorithms to analyse stock exchange blogs from Yahoo Finance.

In research by G. Ranco et al. [4], a controlled machine learning method was applied to find texts' emotional colouring. The resulting data set is a time series of negative, neutral and positive events for each day of disclosure. In the Russian research by E.A. Fedorova, I.S. Demin, L.E. Khrustova et al. [15] a multi-layer neural network was also used. This method is the most resource-consuming, because it requires computer-based knowledge and considerable computation capacities. Application of computer-based education methods helps to obtain a more objective evaluation of the text sentiment.

Thus, in the papers indicated above it was found out that the sentiment of published information may influence corporate share prices [3-5], inter alia, in the Russian stock market [15]. Therefore, we can suggest that when analysing the influence of corporate news sentiment on share prices, the news with more positive emotional colouring will result in a rise in share prices. Thus, the following hypothesis is proposed:

Hypothesis 1 . The sentiment of news about a company positively influences its share prices.

If we compare a continuous indicator of sentiment to division into categories, such as positive, neutral, and negative news, in the second case it is assumed implicitly that any positive news results in identical growth of share prices. In other words, at the threshold value at which the sentiment is defined as positive, the impact of the sentiment does not increase significantly. Therefore, we additionally test the hypothesis of the diminishing marginal effect of sentiment.

Hypothesis 2. The news sentiment impact on share prices diminishes when the sentiment indicator increases.

It is presumed that the sentiment impact on the response of market players may be positive but diminishing, and investors and speculators tend to trust extremely positive news to a lesser degree. It should be noted that the following of share prices is guided according to securities' profitability. Transfer to profitability allows to study the influence of factors on 
share prices and to make a correct comparison of events and companies $[19 ; 20]$ the authors want to see if a surprise (originating from macroeconomic news and GFC events.

\section{Data}

In order to test the influence of the news sentiment on share prices, we collected news about companies included in the Moscow exchange index from the middle of 2017 to the beginning of 2019 (49 companies). These particular companies have been chosen because the Moscow exchange index represents the most liquid securities of the Russian stock market. Securities liquidity is a part of the foundation of this research because due to liquidity we have an opportunity to observe the short-term response of market players to various events. Apart from liquidity, one of the characteristic features of the compiled selection is the existence of available quotes for the period analysed in the research. Initially the selection consisted of 65 securities, however, to make the results more reliable we excluded preferred shares and shares of the companies which have been taken off the quotation list of the Moscow Exchange. See the distribution of companies, which comprised the final selection, arranged by industry, in Figure 1.

Figure 1. The distribution of companies by industry in the final sample

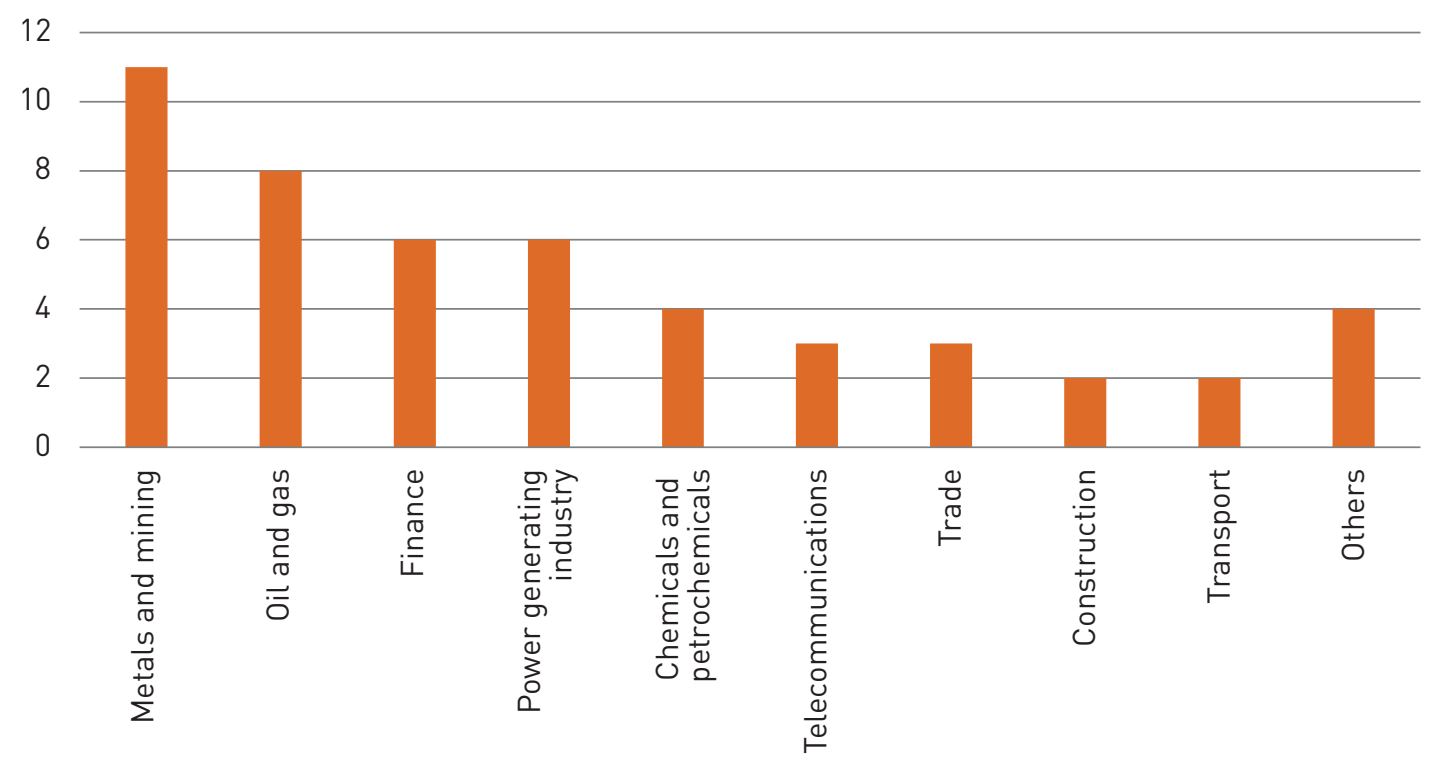

The selection comprises news on dividends and opportunities for the growth of a company, because this type of news is published for the majority of companies, and is the key one for investors. Thus, we ensure the uniformity of a selection. The data on news was collected via the Thomson Reuters information resource. In accordance with the news classification used by Thomson Reuters, we selected news from five categories: capital expenditure, corporate valuation, dividends, revenue drivers, and scalability. The final selection comprised 4,517 news items from about 49 companies. See the distribution of news into categories in Table 1.

Table 1. Distribution of news into categories

\begin{tabular}{|c|c|c|}
\hline Type of news & Thomson Reuters tag & Number of news items \\
\hline Capital Expenditure & CAPX & 572 \\
\hline Corporate Valuation & CVALU & 2 \\
\hline Dividends & DIV & 2,340 \\
\hline Revenue Drivers & REVDRV & 452 \\
\hline Scalability & SCALE & 1,151 \\
\hline Total & & 4,517 \\
\hline
\end{tabular}


For each considered company we collected data on security returns on share as well as the company key performance indicators which characterise the company size, profitability, and financial structure. We also collected data return the Moscow Exchange index (IMOEX) necessary to implement the methodology described below.

Considering financial and non-financial indicators (Table 2) one can notice that on average the companies from the sam- ple have more than a quarter of free float with a small variation. The financial leverage coefficient, on average, amounts to 1.38 for the companies from the selection. However, it should be noted that there are companies which have debt capital in excess of their equity capital by a factor of 26 which means that the company status is unstable and highly risky. There are also companies with a negative financial leverage, due to their negative equity capital.

Table 2. Descriptive statistics of financial and non-financial indicators

\begin{tabular}{|c|c|c|c|c|}
\hline Variable & Average value & Standard deviation & Minimum value & Maximum value \\
\hline Free Float & $29 \%$ & 0.19 & $2 \%$ & $96 \%$ \\
\hline Leverage & 1.38 & 8.51 & -55.22 & 26.04 \\
\hline $\mathrm{ROA}$ & 0.23 & 0.22 & 0.00 & 1.97 \\
\hline dTot.Ass & 0.07 & 0.12 & -0.22 & 0.79 \\
\hline Div/EBIT & 0.32 & 0.24 & 0.00 & 1.33 \\
\hline dRevenue & 0.07 & 0.12 & -0.32 & 2.03 \\
\hline
\end{tabular}

\section{Methodology}

Our methodology for studying the influence of the sentiment of disclosed information on share prices is divided into three stages. At the first stage, we estimate of the news text sentiment with the use of dictionaries. At the second stage, we calculate the abnormal return as an indicator of investors' response to the news by using of the event study method. At the third stage of the analysis, we build a multiple linear regression in which the abnormal return is the dependent variable and the explanatory factors are news categories, and financial and non-financial characteristics of a company which may potentially influence the investors' response.

Sentiment analysis. The algorithm of text sentiment analysis comprises several steps. First, each text paragraph is divided into sentences and each paragraph and sentence is assigned a score. Each set of such sentences is divided into a structured bag of words and assigned a score. The obtained sets of words are purged of punctuation marks, except for commas, colons and semicolons, because they emphasise phrases which differ in sentiment. The second step consists of the search for and comparison of each word of the obtained selection to sentiment dictionary. Each negatively and positively evaluated word is marked with +1 and -1 , respectively. Then the algorithm / the package (or passive voice) - we do not do it manually, it is done automatically divide the text into clusters according to the sentiment of phrases. At the end of the second step we have text clusters, and each of them has its characteristic features (neutral, intensifier or de-intensifier). At the third step, we calculate the general meaning of sentiment for the text. For this purpose we calculate the function on the basis of the number of words in a sentence, clusters in a sentence, and sentences in the text, and also take into consideration the punctuation. The obtained score of sentiment of each sentence of the text is the foundation for calculation of the value of the text sentiment as the weighted average of the score of sentences in the text of each news item under consideration.

Thus, each event's emotional loading is evaluated numerically, where 0 is neutral, greater than 0 is positive, and less than 0 is negative. This method allows us not merely to evaluate the emotional sentiment of news but also to indicate the intensity of such colouring. The bigger the csentiment score, the greater the event's emotional load is.

As noted previously, in this research we used the SentimentR package developed by T. Rinker [21] on the basis of the thesaurus by M. Hu and B. Liu [22] and M. Jockers [23] in order to define the sentiment of corporate news texts. Inasmuch as this tool is developed for English texts we considered news only in the English language.

Abnormal return calculation. The event study method implies observing the response of the stock market (abnormal return measured as) which was caused by the event and defining the statistical significance of the response. Using this method, the researchers focus on the abnormal return which takes place in a short period before and after the event, and is defined as the difference between the actual and normal return, i.e. the expected security return, provided the event has not taken place [17].

In this research, news regarding information on dividends 
or plans related to company development is considered to be an event. For each news item the publication date and actual return on a corresponding security is defined. The normal return may be calculated in several ways, but the most widespread one is the market model in which the dependence between the return of a corporate security and the return of a corresponding stock market index is built. It is supposed that the market index is almost unaffected by a separate corporate event but it takes into consideration all other information in the market. In this research, the normal return model is estimated on the interval of $[-60$; $-30]$, where 0 is the date of the news publication. As long as investors may take account of new information in the share price for a longer time, and also as long as the news publication date may be defined inaccurately, in this research we consider the cumulative abnormal return for 5 days within the interval of $[-2 ; 2]$. The cumulative abnormal return is calculated as the sum of abnormal returns for such time interval.

The factors of the abnormal return. At the third step we apply the regression analysis to assess the influence of the news sentiment on the cumulative abnormal return calculated at the previous stage. Company characteristics and news category are used as control variables of the model, and the impact of the company and year are also added. The change of revenue and assets of the company are included as indicators of the company size change. The revenue change also describes the category of expected revenue, while the assets change reflects - capital investments. The ratio of paid dividends to earnings before interest and taxes (EBIT) was chosen as the indicator which characterises the dividend policy of the company. Following the fundamental analysis theory, it is supposed that market players take a decision on investment mainly on the basis of information of the previous year. Thus, it should be specified that all the above listed indicators were taken with a one-year lag.

So, we get the following equation:

$$
\begin{aligned}
& \mathrm{CAR}_{\mathrm{ij}}=\alpha_{0}+\alpha_{1} \times \mathrm{Sent}_{\mathrm{i}}+\alpha_{2} \times \mathrm{SCALE}_{\mathrm{ijt}}+ \\
& +\alpha_{3} \times \mathrm{DIV}_{\mathrm{ijt}}+\alpha_{4} \times \mathrm{CAPX}_{\mathrm{ijt}}+ \\
& +\alpha_{5} \times \mathrm{REVDRV}_{\mathrm{ijt}}+\alpha_{6} \times \mathrm{CVALU}_{\mathrm{ijt}}+ \\
& +\alpha_{7} \times \mathrm{dREV}_{\mathrm{ijt}}+\alpha_{8} \times \mathrm{dAssetsV}_{\mathrm{ijt}}+ \\
& +\alpha_{9} \times \mathrm{DivEBIT}_{\mathrm{ijt}}+\alpha_{10} \times \mathrm{ROA}_{\mathrm{ijt}}+ \\
& +\alpha_{11} \times \mathrm{GOV}_{\mathrm{ijt}}+\alpha_{12} \times \mathrm{FF}_{\mathrm{ijt}}+ \\
& +\alpha_{13} \times \mathrm{LEV}_{\mathrm{ijt}}+\varepsilon_{\mathrm{ijt}}
\end{aligned}
$$

where

$\mathrm{i}$ - the index of the company;

$j$ - the index of the news;

$\mathrm{t}$ - year of the news item publication;

$\alpha_{\mathrm{i}}, \forall \mathrm{i}-$ model parameters;

$\mathrm{CAR}_{\mathrm{ij}}$ - cumulative abnormal return;

Sent $_{i}-$ event sentiment score;

$\mathrm{SCALE}_{\mathrm{ijt}}$ - dummy variable responsible for the news on the company expansion;
DIV $_{\mathrm{ijt}}$ - dummy variable responsible for the news on dividends;

$\mathrm{CAPX}_{\mathrm{ijt}}$ - dummy variable responsible for the news on capital expenditure;

REVDRV $_{\mathrm{ijt}}$ - dummy variable responsible for the news on revenue drivers;

$\mathrm{CVALU}_{\mathrm{ijt}}$ - dummy variable responsible for the news on the company valuation;

$\mathrm{dREV}_{\mathrm{ijt}}$ - indicator of the annual change of revenue;

dAssets $_{\mathrm{ijt}}$ - indicator of the annual change of assets;

DivEBIT $_{\mathrm{ijt}}$ - ratio of dividends to EBIT;

$\mathrm{ROA}_{\mathrm{ijt}}$ - return on assets ratio;

$\mathrm{GOV}_{\mathrm{ijt}}$ - dummy variable government ownership;

$\mathrm{FF}_{\mathrm{ijt}}$ - Free Float;

$\mathrm{LEV}_{\mathrm{ijt}}$ - financial leverage;

$\varepsilon_{\mathrm{ijt}}$ - error term.

In order to test hypothesis 2 on the diminishing of the marginal effect of sentiment, the square of the sentiment score is added to the model, and an inverted U-shape dependency is presumed.

\section{Results}

As we see from the regression analysis results (Table 3) we discovered a positive influence on investor's reaction of the sentiment of news about the company. In case of increase of the sentiment score by one standard deviation (0.1225), the cumulative abnormal return of Russian companies' shares increases by 0.0026 . It is an economically significant effect, because the average daily return on shares within the period under consideration amounted to 0.0002 . Thus, hypothesis 1 is confirmed and the result is stable for the models under consideration. Consequently, Russian stock market players tend to respond to the news sentiment.

As for hypothesis 2 , it is not confirmed: the sentiment square indicator is insignificant in all models. This proves that the effect of the news sentiment on investors' response does not diminish even at relatively high values of the sentiment indicator.

Analysis of the influence of control variables on the cumulative abnormal return shows that almost all ratios meet expectations. First, state participation in the company shareholding structure increases the cumulative abnormal return by 0.0320 . Consequently, the market players on a short-term horizon respond more strongly to the news about a company with public ownership. This may be related to the fact that companies with public ownership are more exposed to country risk and sanctions risk, and this makes the investors respond to news on development more positively. Second, the Free Float part has an adverse effect on investors' response: when the Free Float indicator grows 
by $1 \%$, the cumulative abnormal return decreases by 0.326 or 0.06 per day, while the daily return on shares is 0.0002 . Such an inverse correlation may be related to the fact that the market players trust more the companies with higher liquidity and more extensive capital in the free market because the companies with a small number of principal shareholders may act in favor of such majority shareholders, and to the disadvantage of minority shareholders. The indicator of the corporate assets change is significant at a $10 \%$ level of significance. So, we may note that in case of an increase of the rate of asset growth by one standard deviation, the cumulative abnormal return is higher by 0.0025 . The dividend payout level (ratio of dividends to EBIT) has a positive impact in investors' response: in case of an increase in the dividend payout indicator by one standard deviation, the cumulative abnormal response of investors grows by 0.0002 . Consequently, if a company develops and pays dividends it is indicative of the company's ability to attract internal and (or) external financing for both mentioned aspects of activity which increase the shareholders' profit. The indicators of return on assets and change of revenue for the previous year, contrary to expectations, have a negative effect on response. Probably, it is caused by the fact that these indicators are taken with a one-year lag and are indicative of the existing corporate development trends. Thus, the companies which previously have been developing quickly should meet the investors' expectations. Apart from that, dummy variables for 2018 and 2019 are positively significant and this testifies towards a more positive investors' response to news about the company development in these years in comparison to 2017. The financial leverage indicator and news categories turned out to be insignificant.

Table 3. Regression analysis results

\begin{tabular}{|c|c|c|c|c|c|c|}
\hline Factor & $\begin{array}{l}\text { Model } \\
\text { without } \\
\text { effects }\end{array}$ & $\begin{array}{l}\text { Model with } \\
\text { effects on } \\
\text { news and } \\
\text { years }\end{array}$ & $\begin{array}{l}\text { Model with } \\
\text { effects on } \\
\text { news, years } \\
\text { and company }\end{array}$ & $\begin{array}{l}\text { Model with } \\
\text { effects on news, } \\
\text { years, company } \\
\text { and company } \\
\text { characteristics }\end{array}$ & $\begin{array}{l}\text { Model } \\
\text { without } \\
\text { effects }\end{array}$ & $\begin{array}{l}\text { Model with } \\
\text { effects on news, } \\
\text { years, company } \\
\text { and company } \\
\text { characteristics }\end{array}$ \\
\hline Sentiment & $\begin{array}{l}0.0212^{* * *} \\
(0.0054)\end{array}$ & $\begin{array}{l}0.0229^{* * *} \\
(0.0057)\end{array}$ & $\begin{array}{l}0.0119^{* *} \\
(0.0056)\end{array}$ & $\begin{array}{l}0.0125^{\star *} \\
(0.0056)\end{array}$ & $\begin{array}{l}0.0301^{\star *} \\
(0.0143)\end{array}$ & $\begin{array}{l}0.0161 \\
(0.0141)\end{array}$ \\
\hline $\begin{array}{l}\text { Square of the senti- } \\
\text { ment indicator }\end{array}$ & - & - & - & - & $\begin{array}{l}-0.0190 \\
(0.0242)\end{array}$ & $\begin{array}{l}-0.0074 \\
(0.0241)\end{array}$ \\
\hline $\begin{array}{l}\text { News on capital } \\
\text { investments }\end{array}$ & & $\begin{array}{l}-0.0522^{\star *} \\
(0.0263)\end{array}$ & $\begin{array}{l}-0.0278 \\
(0.0299)\end{array}$ & $\begin{array}{l}-0.0265 \\
(0.0299)\end{array}$ & & $\begin{array}{l}-0.0265 \\
(0.0299)\end{array}$ \\
\hline News on dividends & & $\begin{array}{l}-0.0479^{\star} \\
(0.0263)\end{array}$ & $\begin{array}{l}-0.0206 \\
(0.0298)\end{array}$ & $\begin{array}{l}-0.0199 \\
(0.0298)\end{array}$ & & $\begin{array}{l}-0.0199 \\
(0.0298)\end{array}$ \\
\hline $\begin{array}{l}\text { News on expected } \\
\text { revenue }\end{array}$ & & $\begin{array}{l}-0.0461^{\star} \\
(0.0264)\end{array}$ & $\begin{array}{l}-0.0233 \\
(0.0299)\end{array}$ & $\begin{array}{l}-0.0226 \\
(0.0299)\end{array}$ & & $\begin{array}{l}-0.0226 \\
(0.0299)\end{array}$ \\
\hline $\begin{array}{l}\text { News on company } \\
\text { expansion }\end{array}$ & & $\begin{array}{l}-0.0535^{\star *} \\
(0.0264)\end{array}$ & $\begin{array}{l}-0.0266 \\
(0.0298)\end{array}$ & $\begin{array}{l}-0.0256 \\
(0.0298)\end{array}$ & & $\begin{array}{l}-0.0256 \\
(0.0298)\end{array}$ \\
\hline 2018 & & $\begin{array}{l}0.0105^{* * *} \\
(0.0024)\end{array}$ & $\begin{array}{l}0.0105^{\star * *} \\
(0.0024)\end{array}$ & $\begin{array}{l}0.0080^{\star * \star} \\
(0.0026)\end{array}$ & & $\begin{array}{l}0.0080^{* * *} \\
(0.0026)\end{array}$ \\
\hline 2019 & & $\begin{array}{l}0.0216^{* * *} \\
(0.0050)\end{array}$ & $\begin{array}{l}0.0203^{* * *} \\
(0.0059)\end{array}$ & $\begin{array}{l}0.0203^{* * *} \\
(0.0059)\end{array}$ & & $\begin{array}{l}0.0350^{* * *} \\
(0.0068)\end{array}$ \\
\hline Public capital & & & & $\begin{array}{l}0.0319^{\star *} \\
(0.0136)\end{array}$ & & $\begin{array}{l}0.0318^{\star *} \\
(0.0136)\end{array}$ \\
\hline Free Float & & & & $\begin{array}{l}-0.3262^{\star} \\
(0.1931)\end{array}$ & & $\begin{array}{l}-0.3255^{\star} \\
(0.1926)\end{array}$ \\
\hline
\end{tabular}




\begin{tabular}{|c|c|c|c|c|c|c|}
\hline Factor & $\begin{array}{l}\text { Model } \\
\text { without } \\
\text { effects }\end{array}$ & $\begin{array}{l}\text { Model with } \\
\text { effects on } \\
\text { news and } \\
\text { years }\end{array}$ & $\begin{array}{l}\text { Model with } \\
\text { effects on } \\
\text { news, years } \\
\text { and company }\end{array}$ & $\begin{array}{l}\text { Model with } \\
\text { effects on news, } \\
\text { years, company } \\
\text { and company } \\
\text { characteristics }\end{array}$ & $\begin{array}{l}\text { Model } \\
\text { without } \\
\text { effects }\end{array}$ & $\begin{array}{l}\text { Model with } \\
\text { effects on news, } \\
\text { years, company } \\
\text { and company } \\
\text { characteristics }\end{array}$ \\
\hline Leverage & & & & $\begin{array}{l}0.0000 \\
(0.0007)\end{array}$ & & $\begin{array}{l}0.0000 \\
(0.0007)\end{array}$ \\
\hline ROA & & & & $\begin{array}{l}-0.1979^{\star * \star} \\
(0.0489)\end{array}$ & & $\begin{array}{l}-0.1979^{\star * *} \\
(0.0489)\end{array}$ \\
\hline Change of assets & & & & $\begin{array}{l}0.0210^{*} \\
(0.0127)\end{array}$ & & $\begin{array}{l}0.0211^{*} \\
(0.0127)\end{array}$ \\
\hline $\begin{array}{l}\text { Ratio of dividends } \\
\text { to EBIT }\end{array}$ & & & & $\begin{array}{l}0.0178^{\star} \\
(0.0105)\end{array}$ & & $\begin{array}{l}0.0178^{\star} \\
(0.0105)\end{array}$ \\
\hline Change of revenue & & & & $\begin{array}{l}-0.0185^{\star} \\
(0.0112)\end{array}$ & & $\begin{array}{l}-0.0184 \\
(0.0112)\end{array}$ \\
\hline Company effects & & & & included & & included \\
\hline Constant & $\begin{array}{l}0.0002 \\
(0.0012)\end{array}$ & $\begin{array}{l}0.0398 \\
(0.0264)\end{array}$ & $\begin{array}{l}0.0186 \\
(0.0304)\end{array}$ & $\begin{array}{l}0.1111^{\star} \\
(0.0597)\end{array}$ & $\begin{array}{l}-0.0009 \\
(0.0168)\end{array}$ & $\begin{array}{l}0.1105^{\star} \\
(0.0596)\end{array}$ \\
\hline $\mathrm{R}^{2}$ & 0.0028 & 0.0141 & 0.0873 & 0.0945 & 0.0029 & 0,0945 \\
\hline $\begin{array}{l}\text { Number of obser- } \\
\text { vations }\end{array}$ & 4,114 & 4,114 & 4,114 & 4,114 & 4,114 & 4,114 \\
\hline
\end{tabular}

***,**,* - significance at a 1,5 and $10 \%$ level, respectively.

News on the study of companies' value, and 2017, have been taken as basic categories.

\section{Conclusions}

This research is dedicated to an analysis of the influence of sentiment of news about Russian companies on the security returns. Based on our research results, we may draw a conclusion as to a positive direct influence of news sentiment on share prices. Thus, the Russian stock market players are exposed to the influence of news sentiment. This result may be due to the fact that investors and speculators are psychologically predisposed to perceive information from the point of view of emotions. It may also be influenced by the economic and political state of the country, in accordance with which each news item may be perceived as either part of a new market decline, or the beginning of a growth phase. It is probable that serious uncertainty keeps the market players in a constant state of tension, and they start taking decisions unreasonably, and on the basis of emotions. Due to the fact that market players often overestimate companies and their prospects on the date that information is published, results may prove greater than expected, and the players quickly purchase the securities of companies where they expect even greater growth. This result may also be aligned with the global geopolitical environment. Each year a new set of sanctions is adopted against Russia, and they limit opportunities for development for different countries. In circumstances of such great uncertainty, the information contained in the news sentiment may prove to be grounds for taking decisions on the allocation of capital. Thus, the sentiment of published news is taken into consideration by Russian stock market players as a part of information, and it influences the dynamics of share prices statistically and economically. It is important to note that the marginal effect of news sentiment does not diminish. This is indicative of a high potential for the news sentiment effect to be used in order to influence market players' response via company management and information intermediaries.

Our results show that Russian public companies should put efforts into the delivery of emotionally positive information to investors. They also should not forget the general company efficiency. Otherwise, share prices may decrease minimally, on a short-term horizon.

Due to the fact that the result of the paper is a significant coefficient of sentiment in terms of specific events, the traders involved in algorithmic trading should include these coefficients in their trading algorithm, together with an analysis of company characteristics.

It should be noted that this research has a series of restric- 
tions. First, we do not present a detailed analysis of news content because of the heterogeneity of disclosed information. Taking into consideration the qualitative and quantitative aspects of information contained in the news (and those factors related to its emotional colouring) may give a more accurate estimate of the effect of sentiment. We also considered news only in English, so this analysis may be insufficient due to a lack of knowledge of the English language by Russian market players. Second, deviation of data from normal distribution could result in inacurrate estimates. Aside from these factors, Russia has a tough economic situation due to sanctions, a dependence of the majority of industries on prices for hydrocarbons, and drops in living standards. Thus, the conclusions in this paper may be displaced with regard to the development of more "normal" economics.

\section{Acknowledgments}

The research has been funded by a grant of the Russian Science Foundation under the scope of project No. 18-1800270 .

\section{References}

1. World Bank Indicators. The World Bank Group. URL: https://data.worldbank.org/indicator/ (accessed on 23.06.2020).

2. Russian stock market: Early 2020. National Association of Stock Market Participants (NAUFOR). URL: https://www.econ.msu.ru/sys/ raw.php? $=65595 \& \mathrm{p}=$ attachment $($ accessed on 23.06.2020). (In Russ.).

3. Soon Y.C. News which moves the market: Assessing the impact of published financial news on the stock market. Master thesis. Singapore: Singapore Management University; 2010. 61 p. URL: https://ink. library.smu.edu.sg/etd_coll/58

4. Ranco G, Aleksovski D, Caldarelli G, Grčar M, Mozetič I. The effects of twitter sentiment on stock price returns. PLoS ONE. 2015;10(9):e0138441. DOI: 10.1371/journal.pone.0138441

5. Tabari N, Biswas P, Praneeth B, Seyeditabari A, Hadzikadic M, Zadrozny W. Causality analysis of twitter sentiments and stock market returns. In: Proc. $1^{\text {st }}$ Workshop on economics and natural language processing (Melbourne, July 2018). Stroudsburg, PA: Association for Computational Linguistics; 2018:1119. URL: https://www.aclweb.org/anthology/W183102 (accessed on 23.06.2020).

6. Healy P.M, Palepu K.G. Information asymmetry, corporate disclosure, and the capital markets: A review of the empirical disclosure literature. Journal of Accounting and Economics. 2001;31(1-3):405-440. DOI: $10.1016 /$ S0165-4101(01)00018-0
7. Acharya V.V., DeMarzo P., Kremer I. Endogenous information flows and the clustering of announcements. The American Economic Review. 2011;101(7):2955-2979. DOI: 10.1257/aer.101.7.2955

8. Granados N., Gupta A. Transparency strategy: Competing with information in a digital world. MIS Quarterly. 2013;37(2):637-641.

9. Berry T.D., Howe K.M. Public information arrival. The Journal of Finance. 1994;49(4):1331-1346. DOI: $10.2307 / 2329188$

10. Lee H., Kweon E., Kim M., Chai S. Does implementation of big data analytics improve firms' market value? Investors' reaction in stock market. Sustainability. 2017;9(6):978. DOI: 10.3390/su9060978

11. Yavorskii V.M., Yavorskaya A.V. The event analysis method on the example of cross-listing data of Russian companies. Vesti vysshikh uchebnykh zavedenii Chernozem'ya. 2015;(1):95-105. (In Russ.).

12. Naidenova Yu.N. Disclosure of information about research and development by Russian pharmaceutical companies. Korporativnye finansy = Journal of Corporate Finance Research. 2015;9(2):100-113. (In Russ.). DOI: 10.17323/j.jcfr.2073-0438.9.2.2015.100-113

13. Yavorskaya A.V. Evaluation of cross-listing influence on the market value of Russian companies.

Korporativnye finansy = Journal of Corporate Finance Research. 2013;7(3):45-54. (In Russ.). DOI: 10.17323/j.jcfr.2073-0438.7.3.2013.45-54

14. Antweiler W., Frank M.Z. The market impact of corporate news stories. 2004. URL: http://citeseerx. ist.psu.edu/viewdoc/download?doi=10.1.1.463.1256\& rep $=$ rep $1 \&$ type $=$ pdf

15. Fedorova E.A., Demin I.S., Khrustova L.E., Osetrov R.A., Fedorov F.Yu. The influence of tonality of CEO letters on the financial performance of the company. Rossiiskii zhurnal menedzhmenta $=$ Russian Management Journal. 2017;15(4):441-462. (In Russ.). DOI: $10.21638 / 11701 /$ spbu18.2017.403

16. Fedorova E.A., Ledyaeva S.V., Fedorov F.Yu., Demin I.S., Denisova T.M. The influence of the level of optimism and the level of narcissism of the CEO on companies' capital structure. Korporativnye finansy = Journal of Corporate Finance Research 2019;13(1):60-75. (In Russ.). DOI: 10.17323/j. jcfr.2073-0438.13.1.2019.60-75

17. MacKinlay A.C. Event studies in economics and finance. Journal of Economic Literature.1997;35(1):13-39.

18. Solodukhina A.V., Repin D.V. The impact of corporate news on the market value of companies. Korporativnye finansy = Journal of Corporate Finance Research. 2009;3(1):41-69. (In Russ.). DOI: 10.17323/j.jcfr.2073-0438.3.1.2009.41-69 
19. Cayon E., Sarmiento-Sabogal J., Shukla R. The effects of the global financial crisis on the Colombian local currency bonds prices: An event study. Journal of Economic Studies. 2016;43(4):624-645. DOI: 10.1108/ JES-12-2014-0201

20. Feng L., Xu W. Has the reform of nontradable shares raised prices? An event-study analysis. Emerging Markets Finance and Trade. 2007;43(2):33-62. DOI: 10.2753/REE1540-496X430203

21. Rinker T. sentimentr: Calculate text polarity sentiment. 2019. URL: https:/CRAN.R-project.org/ package $=$ sentimentr $($ accessed on 23.06.2020).

22. Hu M., Liu B. Mining opinion features in customer reviews. OpenReview.net. 2004. URL: https:// openreview.net/forum?id=ByZ9DgWOWH (accessed on 23.06.2020).

23. Jockers M.L., Thalken R. Sentiment analysis. In: Jockers M.L., Thalken R., eds. Text analysis with R: For students of literature. Cham: Springer Nature Switzerland AG; 2020:159-174. (Quantitative Methods in the Humanities and Social Sciences). DOI: 10.1007/978-3-030-39643-5_14 